AL IBTIDA: JURNAL PENDIDIKAN GURU MI (2018) Vol 6 (1) : 37-48

DOI: http://dx.doi.org/ 10.24235/al.ibtida.snj.v6i1.4036

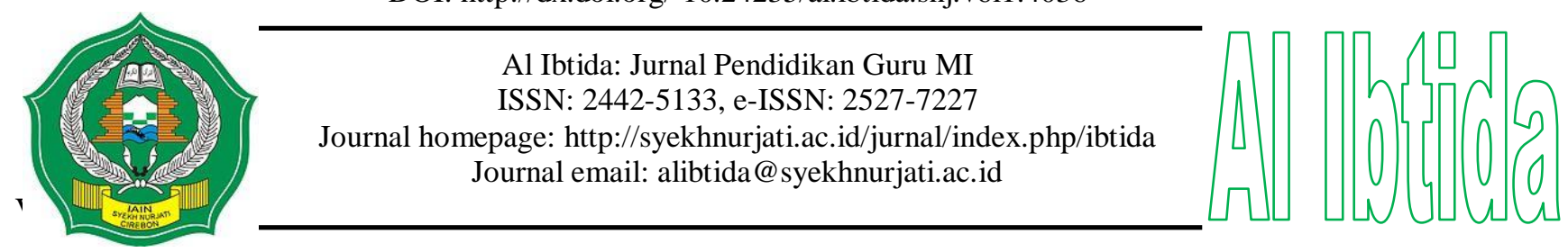

\title{
Optimization of Humanistic Education in the Integrated Islamic Primary School
}

\author{
Asep Kurniawan* \\ *Department of Islamic Education Management, Faculty of Tarbiyah and Teacher Training, \\ IAIN Syekh Nurjati Cirebon \\ Email: asepkurniawan@syekhnurjati.ac.id
}

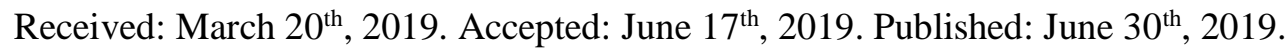

\begin{abstract}
Only a few primary schools apply humanistic education. This could be viewed from the students' moral decadence and the process of dehumanizing education. Even though there are some primary schools implement humanistic education,their application is not maximized. The purpose of the research was to reveal in depth the efforts of Integrated Islamic primary school Sabilul Huda in maximizing humanistic education. This research is a case study of descriptive qualitative. The instruments of data collection are in-depth observation, in-depth interviews, and documentation. Data analysis was conduted conducted through collecting data, reducing data, displaying data, and conclusing data. The research results showed that Integrated Islamic primary school Sabilul Huda maximized humanistic education through applying the principles of humanistic education. It was indicated by the creation of learning conditions through the application of the principles of effective learning. Students contributed actively in finding and processing teaching materials. School viewed students as unique and intelligent individuals. The effort to maximize humanistic education has showed good result, if it was reviewed on academic and non-academic achievements, and students' character. This is indicated by ideal academic scores, achievements in various competitions of interest, talents, and students' good behavior.
\end{abstract}

Keywords: appreciation, uniqueness, joyful, achievement, morality

\begin{abstract}
Abstrak
Tidak terlalu banyak sekolah dasar yang menyelenggarakan pendidikan humanistik. Hal ini dapat terlihat dari dekadensi moral para pelajar dan proses dehumanisasi pendidikan. Kalaupun ada, penerapannya belum maksimal. Tujuan penelitian ini adalah untuk mengungkap secara mendalam upaya SDIT Sabilul Huda dalam memaksimalkan pendidikan humanistik. Jenis penelitian ini adalah kualitatif deskriptif studi kasus. Instrumen pengumpulan data ialah observasi mendalam, wawancara mendalam, dan dokumentasi. Teknis analisis data dilakukan melalui pengumpulan data, reduksi data, display data, dan penarikan kesimpulan. Hasil penelitian menunjukkan bahwa SDIT Sabilul Huda sudah berupaya memaksimalkan pendidikan humanistik melalui penciptaan kondisi belajar yang menerapkan prinsipprinsip pendidikan humanistik. Hal ini ditunjukkan dengan penciptaan kondisi belajar melalui penerapan prinsip-prinsip pembelajaran efektif. Siswa berkontribusi aktif
\end{abstract}


dalam mencari dan mengolah materi ajar yang didapatkan. Sekolah memposisikan siswa sebagai individu yang unik dan anggapan bahwa setiap siswa adalah cerdas. Upaya memaksimalkan pendidikan humanistik sudah memperlihatkan hasil yang cukup baik pada sisi prestasi siswa baik akademik maupun non akademik serta karakter siswa. Hal ini ditunjukkan dengan skor akademik yang ideal, prestasi di berbagai lomba minat, bakat, dan perilaku baik siswa.

Kata kunci: apresiasi, keunikan, suasana menyenangkan, prestasi, moral

\section{INTRODUCTION}

A full day school program is not only developing in Indonesia. Full-day schools have been implemented in a number of countries, such as Germany, Denmark, Spain, Taiwan, the United States, Britain, Japan, China, South Korea, and Singapore. The Harvard Family Research Project published the results of a 2003 study that stated that a full-day school could improve children's social development and personality programs, in addition to academic achievement. Gottfredson, Gerstenblith, Soul'e, Womer \& Lu (2004) have examined students in Maryland in 1999-2000 revealing that students' participation in schools is full of full-day school behavior problems, especially in secondary education students. There are two notes in the results of Gottfredson's study, as quoted in Winurini (2016), first, decreasing behavior is not limited by empty space for adult supervision by increasing student involvement in constructive activities. Second, the activities that most contribute to the decline in behavior problem are activities to develop social competence and personality. The opposite results of the study are explained by Burdumy, Dynarski, \& Deke (2006) through the results of a study released in 2006, they stated that a full-day school program could improve the negative behavior of male students in basic education and students who previously had disciplinary problems. Vandell and Shumow, as quoted by Winurini (2016), revealed that the utilization of full-day schools depends on children opportunities to make decisions and positive climate created in schools that are related to the ratio of students to children and the qualifications of these students. Holm (2014) states that many of full day school system is found in Denmark especially in cities with a high concentration of ethnic minority students.

Heagle, Timmons, Hargreaves, \& Pelletier (2017) argue that there is no significant difference in students' academic abilities who go to school for half a day and a full day's school, but the results of the study show the importance of learning while playing, both in a half-day and a full-day school program . Basketta, Bryanta, Whitea, \& Rhoads (2005) stated that children who attend a full-day school program have improved better than children who attend a half-day school program. In addition, parents also showed a high level of satisfaction with a full-day school program.

There are reasons that need to be learned from the implementation of a full day school 
program in Indonesia. This is because there have been many criticisms during this time on the implementation of education in Indonesia which is considered too burdensome for students. Students are burdened because the curriculum contains too many subjects. Coupled with a fullday school system, of course the burden of students will increase, because students have to spend their time since morning to evening at school. However, the wider community tends to respond positively to the existence of a full-day school. They are not worried that their children feel burdened by the system. This is because even though they learn one full day, they still have enough time to play. In fact, the watchword is learning while playing. Learning is made in pleasant situations so students don't feel overwhelmed. They practice, by borrowing the term of John P. Milner, humanizing the classroom, the learning process that humanizes the class (read: children who study in class). Students are treated according to talents and their own uniqueness. The essence of learning is to increase self-awareness or awareness as the basis of creative intelligence.

This humanist education is increasingly relevant, especially with the current dehumanization conditions nowadays. The KPAI (Indonesian Child Protection Commission) records various children's rights violated in education in 2018. These violations are dominated by violence in the school environment. Retno Listyarti, a Commissioner of KPAI, explained that there were 445 cases of education handled during 2018. "A total of $51.20 \%$ or 228 cases of them were cases of verbal, sexual, or physical violence." The majority of physical violence experienced by students in schools was done by the educator. The actions range from sit up, push up, licking toilets, drying out, to slap, commanded to smoke and recorded by a camera. Sexual abuse is also often carried out by teachers and occurs in schools, especially in elementary school. The victims were not only female students but also male students. Even the tendency in 2018 is that more vulnerable male students are victims of sexual abuse. Of the 177 students, 135 of them were male students (Setyawan, 2018).

For this reason, the government, practitioners, experts, or other components of society propose a number of educational theories that are considered appropriate to be implemented in this country, both with the nuances of Indonesian values and the spirit of local culture, or those who take education systems from abroad. However, not many have shown partiality towards the dimension of developing a humanist side comprehensively. Even though education should be oriented towards efforts to develop and actualize human potentials intact and integrated.

The solution to the application of humanistic education is believed to be able to solve the problem comprehensively and touch something that is very fundamental to the nation's problems. Humanistic education is education that gives high appreciation to all individuals or is studentcentered (Power, Nuzzi, Hunt, Narvaez, \& Lapsley, 2007). Emphasizing the importance of the 
learner's inner world and placing the thoughts, emotions, and feelings of individuals as the foremost part in all human development (Khatib, 2013) and regard humans as creatures that have abilities that can be grown (Baharudin \& Makin, 2007).

Unfortunately there are not many educational institutions in Indonesia that implement humanistic education systems, especially in elementary schools. A number of educational institutions tend to strive to be excellent in academic areas alone, or offer the luxury of learning infrastructure with the consequences of very expensive education costs. Parents also have a tendency to send their children to school that offers academic achievement success or guaranteed employment after graduation.

Of the small number of elementary schools that implement humanistic education, the SDIT (Integrated Islamic Primary School) of Sabilul Huda Cirebon is among them. This school is a private school and has committed to implement a humanist education system, by treating students as a whole and unique person (observation dated on April 05, 2018). Through learning model that varies education in the classroom, outside the classroom, and playgrounds, all students are given the freedom to explore their curiosity. In the vision and mission of the institution has been written that the institution explores and guides each student to recognize his potential to be optimally developed. For this reason, this study aims to reveal in depth the optimization of SDIT Sabilul Huda in implementing, developing humanistic education and how the results achieved.

\section{METHODS}

This study used a qualitative descriptive approach of case studies by field study (field research) that is intended to understand the phenomenon of what is experienced by the subject of the research: for example, behavior, perception, action and others, holistically and by description way in the form of words and language, in a special context naturally and by utilizing various scientific methods (Moleong, 2004). Researchers act as collectors as well as data instruments. The position of the researcher is the maker of the plan, data collector, analyzer, data interpreter, and reporter of the results of his research. The instruments of data collection are indepth interviews, in-depth observations, and documentation.

This research was conducted for approximately 5 months starting from April 5, 2018 to August 20, 2018. The location of the study was Sabilul Huda Integrated Islamic Primary School (SDIT) located at Perjuangan Street, Cirebon City. Data analysis is done inductively. Meanwhile, the analysis model used is the interaction analysis model, where the data reduction and data display stages are carried out together with the data collection process. After the data are collected, data reduction were carried out, data displayed, and conclusion drew out. 


\section{RESULTS AND DISCUSSION}

\section{Efforts of SDIT Sabilul Huda in Maximizing Humanistic Education}

SDIT Sabilul Huda seeks to implement learning models that pay attention to the psychological development of their students. Developing learning habits are in harmony with students psychological. . Because the school understands that playing is the childrens' world. . Then the learning process of students unites with the world of play. SDIT Sabilul Huda creates an innovation program in the world of education by implementing learning models that make students happy when the learning takes place (joyful learning). The principle is that students can learn effectively if they are in a comfortable and pleasant atmosphere so that students become at home learning (interview with Yusuf, head of SDIT Sabilul Huda May 7, 2018).

This program cannot be separated from its curriculum which pays attention to the development of students' psychological. The common monotonous learning activities are changed by fun learning activities with making some variations of classroom learning outside , such as in parks, gardens, school yards, mosques, halls and a number of other places such as outbound is also often used as a place of learning. Learning material is not only based on theoretical and conceptual. Students are invited to learn from concrete things with simulations, practices, games (games), demonstrations and others to avoid verbalism. For example in science learning students learn about volcanoes while making volcanoes replica from certain materials including caustic soda as its lava.

According to the explanation of the SDIT teacher, Nenti (interview June 10, 2018), usually with a variety of student competencies, the student's learning style is also different. SDIT Sabilul Huda adopts learning process approach; outdoor and indoor. It is hope to respond the demands of each student's learning style. For students with auditory learning styles, they will get a lot of things when learning in the classroom. Meanwhile, students who have kinesthetic and visual styles might get a lot of activities outside the classroom.

A similar statement was also expressed by Novi, one of the student's parents of SDIT Sabilul Huda. According to her, among the proofs that this school truly maximizes humanistic education is the placement of students as the center of the learning process.

As far as I know, my child always likes to go to school. He always seems passionate about learning in school. Because it was designed not to go in one direction, the teachers played themselves only as facilitators. Questions exercising that are often given were essay types, not just multiple choices. With this type of question my child can freely answer, as long as the answer does not deviate from the question, the teacher will still justify the answer. Besides that, at SDIT Sabilul Huda students were given contextual writing assignments such as recounting holiday experiences, including I was touched by a letter from my child who expressed his love for me as his mother right on Mother's Day December 22. I think learning like this is very good for training children in expressing their opinions and feelings (interview with Ms. Novi June 8, 2018). 
SDIT Sabilul Huda views students as being educated in accordance with their age. Read and write new taught in grade 1 SDIT. This means that to be accepted as SDIT students, the child is not tested for reading and writing competence. Student's literacy ability is not used as a guide for the acceptance of new students. The test is only in the form of motor skills and language skills through interview tests, which are all designed in pleasant condition. This test is carried out as an effort to find out the student's intelligence model. Schools do not accept students because of their intelligence; they see that every student is intelligent.

In its development the teachers will help students find their dominant intelligence, whether they have kinesthetic intelligence, mathematical, or even intelligent in the field of art, and that intelligence is grown, developed, and facilitated with awareness that all children have a unique, and important to respect others, and grow the awareness to need each other.

SDIT Sabilul Huda applies the principles of effective learning namely, student centered learning, meaningful learning, joyful learning, the daily life problem solving, and learning by doing. Besides that, the education process is supported by the proportion of teachers and ideal students, because in one class there is one teacher and 25 students. Even in low classes such as grades 1, 2 and 3 one class is taught by two teachers. Meanwhile according to Minister of Education and Culture Regulation Number 23 of 2013, Article 2 Point 2 states that the ratio of elementary / MI (Islamic Elementary) students in one study group does not exceed32 people. Therefore, this proportion is ideal, so that supervision of student activities can be optimal, teacher-student interaction is relatively intensive, teacher's understanding of each student's character becomes more complete because it is obtained from two teachers, and leads to unequal treatment of student learning styles.

Among the forms of humanistic education that the author found in the process learning at SDIT Sabilul Huda is the involvement of students in the process of seeking knowledge. Teachers do not make students passively. The learning also avoids non-educative penalties such as threats, physical punishment, shouting and so on.

If viewed from how SDIT Sabilul Huda designed the learning, it was included in the category of schools with humanist education. Humanist education is education appreciated in high education to all learners, placing it as individuals who have the potential to be actualized and developed (Marbaniang, 2009). The humanist learning model has a number of indicators, they are: (1) Student centered learning, (2) Humanizing classrooms, (3) Active learning, (4) Quantum learning, (5) Quantum teaching, and (6) Accelerated learning (Atrisna, 2006). The meaning and usefulness of the learning process is determined by the learner, not the educator. Therefore, the design and learning methods must be developed by participants based on the students' needs (Untari, 2016). 
As the findings in the field, that SDIT Sabilul Huda has carried out a number of efforts to maximize humanistic education. Among them is by designing schools to create comfortable conditions in students learning activities. The learning place does not only in a classroom bordered by wall, narrow, but also in the outdoor, such as the market, mosques, gardens, school yards, and so on. The awkward learning process were not found in this school,, but varied, and quite enjoyable learning. Students not only learn from the theories conveyed by the teacher, but also they are involved in the process of learning to gain knowledge through thinking, observing, and practicing. Student involvement like this as evidenced by a lot of research can lead to students' extrinsic motivation. The study conducted by Saeed \& Zyngier (2012), for example, that the majority of students' involvement in learning in elementary schools has shown the influence of the emergence of extrinsic motivation and in turn affects learning achievement.

SDIT Sabilul Huda teaches lesson material in the form of concrete things, from things that are commonly known by students because they are in the environment around them. In this way the students learn more easily, because the subject matter has a relationship with many actual problems that exist in the surrounding environment. Submission of subject matter in the form of concrete things is in accordance with the stages of development of student thinking expressed by Piaget. The age of elementary school students aged between 6 to 11 years, according to Piaget is at the stage of concrete operational thinking. At that age students begin to think logically about objects that exist in their environment, and act mentally which had previously been done in the actual conditions. In this phase, the cognitive is used at the first time on a consistent stage. Children can sort and arrange objects according to size, weight, and color. In the next stage the child will understands conservation law; the principle explains that an object will remain substantive even though it has changed its structure or form (Joubish \& Khurram, 2011).

In the research findings data were obtained about the placement of students as the center of learning activities. Teachers pay attention to the human side of students, which is trying to understand their minds. What is being felt and thought by students is used as a reference for designing learning. The teacher as a facilitator has a dialogue to influence and direct students' perceptions to be better. It is important for the teacher to help students get meaning from the subject matter and connect it to their lives by understanding students' behavior on how they perceive their actions (Coe, Aloisi, Higgins, \& Major, 2014). Theory of Humanistic learning also focuses on the principle application of student-centered learning. A humanist education facilitator only has to show the significance of a material teaching to each student. Through this matter, education will be able to avoid threats, and coercion, as well as workloads that are beyond the limits of ability. This is as evidenced in humanistic education research conducted by 
Johansson's (2006) point out that after students are given various choices of teaching materials according to their interests, students have enthusiasm in learning. This research is confirmed by research conducted by Gak (2011).

SDIT Sabilul Huda is designed to be a comfortable place. This school hopes that students enjoy to stays long in the school environment. The academic climate in schools is changed to be more comfortable and friendly to students, by providing a variety of playing facilities and giving space for students to actively move and the class is quite comfortable. This finding certainly confirms the results of the study which explains that classroom management carried out by the teacher raises positive student behavior, and minimizes students' lack of good behavior. The teacher regulates the conditions and learning facilities needed such as the classroom environment, teaching equipment and materials, seating, and others. A survey of 450 elementary school teachers assigned to the Turkish city of Antalya by Kayıcçı (2009) showed that there was a significant relationship between classroom management skills and student discipline behavior. The dimensions of teacher classroom management skills are important predictors in student discipline behavior.

\section{Program to Maximize Humanistic Education}

Researchers get the general condition of physical building SDIT Sabilul Huda which has facilities to support students as a place to learn character education, worship, and manners. This school also completed by a large mosque, a large yard, a healthy canteen, and a pretty beautiful environment. The humanist side of human beings who acknowledge the existence of God is implanted with the habit of worshiping, such as the Dhuha prayer, the dhuhur prayer and Asr in congregation and Friday prayers. This activity is carried out by all members of school.

Character and courteous character education starts from the beginning of learning in the morning, where students are accustomed to reprimand, greeting, and greetings when they arrive at the school gate to be welcomed by the teachers. The program is also intended to give students examples of character, manners, and discipline, as well as to create enthusiasm for students to take part in learning. Included in this issue, the internalization of courtesy value and discipline also conducted through games under the teacher control. Students are trained in culture of queuing, mutual respect, and cooperation. Seen in the findings, students seemed orderly waiting their turn to be able to use playing facilities, such as slides, swings, fields for playing football, and others.

Besides being committed to making schools not as a place of transfer of knowledge, SDIT Sabilul Huda also believes that students can learn from everyone and everywhere, or that in the principles of SDIT Sabilul Huda the terms a place of learning are used anywhere and from anybody. All places can be used as a place to learn. On a number of occasions, for example, 
teachers invited students to the Newspaper Office Radar Cirebon, Fire Extinguisher, Gua Sunyaragi, Cirebon port, and others.

Among the focuses of humanist education is the view that all students are individuals unique, all students have advantages and the task of the teacher is only to direct it. For this reason, at SDIT Sabilul Huda, many extracurricular programs aim to accommodate students' talents and interests, namely: sports such as futsal, swimming, karate, arts such as art, drum bands, and intellectual extracurricular activities such as English club, mathematics, club science. Not to mention, some programs are added at certain times. For example Okat (Great children's Olympics) which is intended to showcase students' abilities, capability and talents, such as the work of students be like drawing and others (interview with Yusuf, July 10, 2018).

Other programs such as outbound, camping, mabit (a night stayed) muhasabah, Islamic boarding school at Ramadan, art performances were held as part of the sincerity of this school in maximizing humanistic education. These programs are designed to provide useful experiences to students regarding humanist values including worship, life skills and discipline. Every element in this institution is designed to be humanistic and conducive. Humanist impression can be felt since entering the school area. The researcher felt friendliness, greetings and greetings from the school members, namely security guards, administrative staff, teachers and principal.

SDIT Sabilul Huda provides a large portion of parents to be involved in mentoring student learning and involvement in various school activities. This is to participate in the success of student learning. For example, the author found teachers asking parents to practice reciting and memorizing the Koran at home. Likewise, each division of student report cards is submitted directly to parents/guardians of students. Teachers explain the condition of their children; strengths and weaknesses to be able to be a concern of parents so that students can be established at home, and so on.

Furthermore, they received the school program agenda to be held for a year from each homeroom. Through this effort, parents can find out what the school needs to prepare for their children's learning activities. In addition to this, parents can help prepare the entire agenda as well as possible, because they have known since long ago. The parents can also provide input in the form of suggestions or criticism for the success of the agenda. The school also established a communication forum for parents of students through the school committee. In this forum management is organized which has work agendas. In the forum parents discussed the learning process of their children while studying at SDIT Sabilul Huda and became a place of communication between parents and the school. 


\section{Results of Efforts to Maximize Humanistic Education in SDIT Sabilul Huda}

The form of humanization in the concept of education developed at SDIT Sabilul Huda is seen in the education results. This school does not really target the high values listed in report cards, diplomas or National Examinations (UN) as an indicator of children's success. As explained by Mabrur Fauzi as the parents of students and former heads of SDIT Sabilul Huda, that this school received the title of a school that held high honesty in the UN. Schools do not commit cheating such as making a " success team" to "help" students answering questions, provide cheats and others. Honesty is everything (interview August 14, 2018). This means that this school focuses more on good behavior. The results that the researchers got were the recognition of many parents who interviewed by researcher, they were generally satisfied with education at SDIT Sabilul Huda. This is indicated by the behavior of their children who do not leave the prayer, are able to sing a number of daily prayers, have great respect for the parents, and maintain honesty, say politely and others. Not surprisingly, this school is always flooded with interested people.

However, based on data, students' achievement in the academic field is quite good. This can be seen from the average score of the National Examination which averages 75. Likewise the value of report cards that have exceeded the KKM value of 7.5, namely the average student learning outcomes in all classes ranges in number 8 . Not inferior to academic achievement, Nonachievements were academic achieved very well. Many championships at the city or provincial level are inscribed by this school. Like The First Winner of Story Telling in Cirebon City in 2016, won 5 gold medals and 12 silver medals in the martial arts competition between students held by the Cirebon IPSI in Grage City in 2017, and others.

Parents can see and feel the results of the learning model implemented at SDIT Sabilul Huda. Knowledge gained by students is quite deep, because the learning process is associated with daily life. As with the material counted in mathematics, after getting the subject matter, students apply their knowledge directly in buying and selling activities. Like the recognition of several students, Irfan Faris and Oi who claimed to have studied at the Kalitanjung Market and practiced buying and selling with their own friends in class (Interview August 20, 2018).

The findings of the study at SDIT Sabilul Huda focus on learning outcomes not only on the high scores listed on diplomas, report cards, or national examination or as an indication of the success of students. However, it focuses on giving good personal provision and life skills to students. The school believes that all students have privileges with a potential diversity that must be developed so that they can continue to grow and lead to the actualization of selfpotential. What is implemented in this school is in accordance with the goals of humanist education, namely the creation of a pattern and educational process that always positions humans 
as creatures who have various potentials either spiritual, psychological, or physical, who must get guidance. What must be noted is that each potential is different from one another (Aloni, 2014).

The findings of this study are in line with the theory of research results put forward by Elkanova \& Chedzhemova (2013) that education is a process of human humanity (humanization), which is aware of an independent human being. An independent human is a creative human being created in his culture, the creation of a human social education system that is in accordance with the values and ideals of humanism.

\section{CONCLUSION}

SDIT Sabilul Huda has tried to maximize humanistic education. This is done by creating learning conditions through the application of student centered learning principles, joyful learning, meaningful learning, active learning, the daily life problem solving, quantum learning, and quantum teaching. In this case students contribute actively in finding and processing the teaching material obtained. The school positions students as unique individuals and assumes that each student is intelligent. In accordance with that, teachers vary the methods, learning media, giving trust, appreciation, and responsibility to build self-confidence and optimize their competencies. In addition, there is a good synergy between family and school in the process of mentoring student development. Efforts to maximize humanistic education have shown quite good results on the student achievement side, namely (1) academic achievement in the form of an average National Examination score of 75, report cards that have exceeded the KKM score of 7.5 , and the average yield student learning in all classes ranges in number of 8., Further, nonacademic achievements and student character are indicated by achievements in various art and sports competitions as well as students' polite and well manner - behavior. In conclusion, this humanistic education needs to be encouraged to be in accordance with the purpose of education, which is to humanize humans.

\section{REFERENCES}

Aloni, N. (2014). Humanistic Education. Encyclopaedia of Educational Philosophy and Theory. Tel Aviv-Yafo, Israel: Kibbutzim College of Education.

Atrisna. (2006). Implikasi Teori Belajar Carl Rogers dalam Pendidikan. Yogyakarta: Pustaka Pelajar.

Baharudin \& Makin. (2007). Pendidikan Humanistik; Teori dan Aplikasi Praksis dalam Dunia Pendidikan. Yogyakarta: Ar-Ruzz Media.

Basketta, R., Bryanta, K., Whitea, W., \& Rhoads, K., (2005). Half-day to Full-Day Kindergarten: An Analysis of Educational Change Scores and Demonstration of an Educational Research Collaboration. Early Child Development and Care, 175(5), 419430. 
Burdumy, J. S., Dynarski, M., \& Deke, J. (2006). After-School Program Effects on Behavior: Results from the 21st Century Community Learning Centers Program National Evaluation. Economic Inquiry, 46(1), 13-18.

Coe, R., Aloisi, C., Higgins, S. \& Major, L., E.. (2014). What Makes Great Teaching? Review of the Underpinning Research. Durham DH1, UK: Durham University.

Elkanova, T. M. \& Chedzhemova, N., M. (2013). Humanization and Humanitarization of Education: The Essence, Principles, Aims. World Applied Sciences Journal, 22(5), 697702.

Gak, D. M. (2011). Textbook-an Important Element in the Teaching Process. Novi Sad, Serbia: Fakultet tehničkih nauka - Engleski jezik, Novi Sad.

Gottfredson, D. C., Gerstenblith, S. A., Soul'e, D.A., Womer, S.C., \& Lu, S. (2004). Do After School Programs Reduce Delinquency? Prevention Science, 5(4), 253-266.

Heagle, K., Timmons, K., Hargreaves, F., \& Pelletier, J. (2017). The Social Kindergartener: Comparing Children's Perspectives of Fulland Half-Day Kindergarten, 187(5-6), 978989.

Holm, L. (2014). Parental Perspectives on Danish Full-day Schools for Ethnicminority Students. International Journal about Parents in Education, 8(1), 26-33.

Johansson, T. (2006). Teaching Material in the EFL Classroom: Teachers' and Students' Perspectives. Växjö, Swedia: Växjö University.

Joubish, M., F. \& Khurram, M., A. (2011). Cognitive Development in Jean Piaget's Work and its Implications for Teachers. World Applied Sciences Journal, 12(8), 1260-1265.

Kayıç̧ı, K. (2009). The Effect of Classroom Management Skills of Elementary School Teachers on Undesirable Discipline Behaviour of Students. Procedia Social and Behavioral Sciences, 1, 1215-1225.

Khatib, M. (2013). Humanistic Education: Concerns, Implications and Applications. Journal of Language Teaching and Research, 4(1), 45-51.

Marbaniang, D. (2009). Developing the Spirit of Patriotism and Humanism in Children for Peace and Harmony. Children At Risk: Issues and Challenges, Jesudason Jeyaraj (Ed.). Bangalore: CFCD/ISPCK.

Moleong, L. J. (2004). Metodologi Penelitian Kualitatif. Bandung: PT. Remaja Rosdakarya.

Power, F. C., Nuzzi, R.J., Hunt, T.C., Narvaez, D., Lapsley, D.K. (2007). Moral Education. Westport, Connecticut, United States: Greenwood Publishing Group.

Saeed, S. \& Zyngier, D. (2012). How Motivation Influences Student Engagement: A Qualitative Case Study. Journal of Education and Learning, 1(2), 252-267.

Setyawan, D. (2018). KPAI Soroti Maraknya Kasus Kekerasan Anak di Awal Tahun 2018. http://www.kpai.go.id/berita/kpai-soroti-maraknya-kasus-kekerasan-anak-di-awal-tahun2018 (diakses 3 Maret 2019).

Untari, L. (2016). An Epistemological Review on Humanistic Education Theory. Jurnal Leksema, 1(1), 59-72.

Winurini, S. (2016). Wacana Penerapan Full Day School Untuk Siswa SD dan SMP. Majalah Info Singkat, Vol. VIII, No. 15///P3DI/Agustus. 